\title{
確率有限要素法における破壊確率計算法の提案

\author{
A NEW METHOD FOR CALCULATING FAILURE PROBABILITY \\ WITH THE STOCHASTIC FINITE ELEMENT METHOD
}

\author{
溜 幸生* ・桜井春 輔**
}

By Yukio TAMARI and Shunsuke SAKURAI

\begin{abstract}
Recently a stochastic finite element method (SFEM), which can treat stress analyses with stochastic variability, has been drawing attention particularly in the field of geotechnical engineering. This is due to the fact that design parameters such as material constants, external loads, etc., must be regarded as random variables.

In an ordinary SFEM, the probability density functions are usually assumed to be a normal distribution. The distribution of uncertainty, however, does not always follow the normal distributions in geotechnical engineering problems. Therefore, difficulties may arise when applying SFEM to non-normal distribution problems.

In this paper, a new method is proposed in order to overcome the above-mentioned difficulty of calculating failure probability. In the proposed method, the failure criterion is linealized at the failure point, and failure probability can be calculated on the integration of the linealized failure criterion by using random numbers.

Some numerical examples are demonstrated to verify the proposed method.

Keywords: failure probability, stochastic finite element method, non-normal distribution, random numbers
\end{abstract}

\section{1. まえがき}

最近, 地盤にかかわる構造物の設計において, 数值解 析は欠かすことのできない重要な手法となりつつある. その中でも有限要素法は, 材料の非均質性, 不連続性, 複雑な境界条件などを, 比較的容易に解析に取り入れる ことができるため, 種々の地盤構造物に対してよく用い られるようになった1) -3).

しかし, 解析に際しては, 地盤の材料定数を原位置に おいて正しく評価し, 唯一的に决定することが要求され るが,一般に, 原位置試験などで求められる材料定数は, ばらついた值をとるため, 解析に用いるインプットデー 夕としての材料定数を唯一的に, 正しく求めることは非 常に困難である.そこで，このような場合には，従来， 原位置試験などで得られるばらついたデー夕に対して代 表的な值，たとえば，平均値，上限値，下限值などを選 定し，これらを用いてパラメータースタディを行ってき たが, 最近では, 地盤の材料定数のばらつきのような不

* 正会員 工修 東電設計 (株) 第二土木本部火力土木部 (元・神戸大学大学院修士課程学生)

（テ100 千代田区内幸町 2-1-1)

** 正会員 $\mathrm{Ph}$. D., 工博 神戸大学教授 工学部土木工学科 （于657 神戸市灌区六甲台町 1-1）
確定性を確率論によって定量的に評価しようとする信頼 性解析や信頼性設計が提案されてきている! ? ${ }^{4)}$.

有限要素法において, 不確定性を有する材料定数を確 率量ととらえて解析する方法として, 確率有限要素法が 提案されている77,8). 地盤工学においても，この方法を 用いて構造物の信頼性解析や信頼性設計の試みがなされ

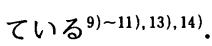

Cambou $^{9)}$ は, 有限要素法に基づくモンテカルロ法に よって信頼性解析を行うことは多大な計算機費用がかか ることから，有限要素法に線形一次近似理論を適用し， 解析的に変位と応力の平均值と分散を求める方法を示し た (以下, これを確率有限要素法という). さらに, 桜 井ら ${ }^{10)}$ はCambou が提案した確率有限要素法に材料の 破壊規準を与えることによって，各要素のせん断破壊お よび単一すべり面が存在するときの全体破壊のそれぞれ に対して破壊確率を求める方法を提案し，これを斜面の 信頼性解析に適用した。鈴木ら ${ }^{11}$ は，桜井らの提案した 方法に Hasofer と Lind の提案した安全性指標 $\beta^{(2)}$ を用 いて破壊確率を計算する方法を示し，斜面の安定解析を 行った. 辰巳ら ${ }^{13), 14)}$ は, 土構造物についても, 耐用年数 を考慮した信頼性設計が必要であり，耐用年間での破壊 確率と損失費用をかね合わせて，総費用を最小にする最 
適設計が望まれるとして, 確率有限要素法を用いて護岸 の信頼性設計を試みている.

確率有限要素法によると，材料定数や外力を確率変数 とし, それらの平均值, 分散, 分布形をインプットデー 夕として与えることにより, 変位および応力の平均值, 分散が算出される. また, 種々の破壊の状態を定義する 破壊規準を与えることによって，それぞれの破壊形態に 対する破壊確率を計算することも可能である. しかし， これまでの研究で提案されている確率有限要素法は，一 般に, 不確定要因に対して正規分布を仮定して破壊確率 を求めるものである. それゆえに，実際の地盤構造物に かかわる不確定要因が正規分布に従うときは，破壊確率 は正解值 (モンテカルロ法で求めた解) と一致する. と ころが, 地盤構造物にかかわる不確定要因は必ずしも正 規分布に従うものばかりでないことが指摘されてお $り^{13), 15)}$ 正規分布でない分布形に対して，破壊確率を求め た場合, 正解値とは一致しないことが確認されている ${ }^{14)}$. そこで, 地盤構造物にかかわる不確定要因の分布形が複 雑な分布形，たとえば対数正規分布やワイブル分布に従 う場合であっても，正確にかつ容易に破壊確率を計算す る確率有限要素法の開発が必要となる.

本論文においては，まず，有限要素法において，各要 素の破壊規準関数（破壊の状態を定義する関数）を破壊 点において線形化する方法を具体例を挙げて説明し，次 に，線形化された破壊規準関数をもとに，複数の確率変 数からなる結合確率密度関数から, 乱数を発生させるこ とによって破壊確率を計算する方法を提案する.そして, 具体的な解析例を示し，モンテカルロ法による解と比較 検討を行う.

なお，ここでは簡単のために，不確定要因は空間的に ばらつかず (完全相関), 互いに独立であると仮定する. また，解析は二次元平面ひずみ状態で行い，有限要素法 においては一定ひずみ三角形要素を用いる.

\section{2. 有限要素法における破壊規準関数の線形化}

\section{（1）破壊規準関数の定義}

破壊確率を計算するには，破壊規準関数の定義が必要 である. 確率有限要素法を用いる場合に，いくつかの破 壊規準関数が提案されているが，ここでは，局部破壊10) について考える.

一般に, 要素 $i$ の破壊規準関数を， $Q_{s i}$ とすると, $Q_{s i}<0$ のとき，応力状態が破壊規準を超えるため，そ の要素は破壊する.ここで, $Q_{s i}$ は， $m$ 個の不確定要因 $\{r\}=\left\{r_{1}, r_{2}, \cdots, r_{m}\right\}$ の関数であり, $\{r\}$ は, ヤング係数, ポアソン比, 単位体積重量, 粘着力, 内部摩擦角, 荷重 など，の関数である.すなわち

$$
Q_{s i}=Q_{s i}\left(r_{1}, r_{2}, \cdots, r_{m}\right)
$$

と表わされる.

いま, $Q_{s i}$ の具体例として，せん断に対する要素 $i$ の 局部破壊の安全性の余裕を考える。ここで，クーロンの 破壊規準を用いると, 要素 $i$ の応力状態とクーロンの破 壊規準の関係は，図一1のように表わされる。なお，こ こでは圧縮を正とする．要素 $i$ において，モールの応力 円の中心から破壊規準までの距離を $\tau_{f l}$, 応力円の半径 を $\tau_{\max i}$ とすれば, 次式が定義できる.

$$
\begin{aligned}
& Q_{s t}=\tau_{f t}-\tau_{\max i}=c \cos \phi+\frac{1}{2}\left(\sigma_{1 i}+\sigma_{2 i}\right) \sin \phi \\
& -\frac{1}{2}\left(\sigma_{1 i}-\sigma_{2 i}\right)
\end{aligned}
$$

ここで, 要素 $i$ の主応力 $\sigma_{1 i}, \sigma_{2 i}$ は, ヤング係数, ポア ソン比, 単位体積重量, 荷重の関数である.

式（2）からも明らかなように， $Q_{s i}<0$ になれば, 応力状態が破壊規準を超えるため，材料が破壊すること になる。

\section{（2）破壊規準関数の線形化}

式（2）で表わされた破壊規準関数を，各要素の破壊 点 $\left\{r_{i}^{*}\right\}=\left\{r_{1 i}^{*}, r_{2 i}^{*}, \cdots, \quad r_{m i}^{*}\right\}$ において線形化する.ここ で破壊点とは, Hasofer と Lind が提案したもので, 確 率的に最も破壊しやすい確率変数の組で表わされる点で あり

$Q_{s i}\left(r_{1 i}^{*}, r_{2 i}^{*}, \cdots, r_{m i}^{*}\right)=0$

を満たすものである. 破壊点は, 一般に, 収束計算によっ て求めることができる ${ }^{16), 17)}$. 局部破壊の場合は各要素に ついて収束計算を行う。

いま, $Q_{s i}$ を不確定要因 $\{r\}$ の要素 $i$ の破壊点 $\left\{r_{i}^{*}\right\}$ の 近傍でテーラー展開し，二次以上の高次の項を無視すれ ば, 式（3）を考虑して次式を得る.

$$
\begin{aligned}
& Q_{s i} \simeq Q_{s i}\left(r_{1 i}^{*}, r_{2 i}^{*}, \cdots, r_{m i}^{*}\right)+\left.\sum_{k=1}^{m}\left(r_{k}-r_{k i}^{*}\right) \frac{\partial Q_{s i}}{\partial r_{k}}\right|_{*} \\
& =\left.\sum_{k=1}^{m}\left(r_{k}-r_{k i}^{*}\right) \frac{\partial Q_{s i}}{\partial r_{k}}\right|_{*}
\end{aligned}
$$

ここで, $\partial Q_{s i} /\left.\partial r_{k}\right|_{*}$ は, 偏導関数 $\partial Q_{s i} / \partial r_{k}$ の $r_{t i}^{*}, r_{2 i}^{*}$, $\cdots, r_{m l}^{*}$ における值であり， $Q_{s i}$ が式 $(2)$ で定義され る場合，次のように求められる。なお， $r_{m-1}, r_{m}$ はそ

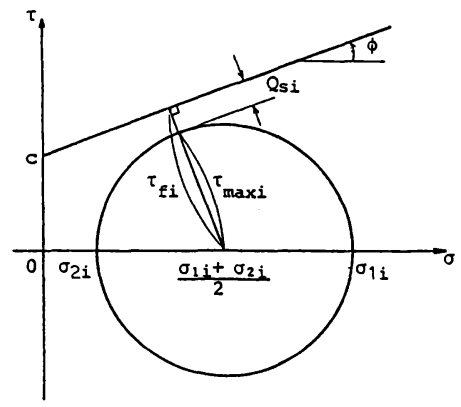

図-1 破培規準関数 $\boldsymbol{Q}_{\boldsymbol{s} \boldsymbol{}}$ （安全性の余裕） 
れぞれ $c, \phi$ を表わすものとする.

$$
\begin{aligned}
k=1,2, \cdots, m-2 \text { のよき } & \left.\frac{\partial Q_{s i}}{\partial r_{k}}\right|_{*}= \\
& \left.\frac{1}{2}\left(\sin \phi_{i}^{*}-1\right) \frac{\partial \sigma_{1 i}}{\partial r_{k}}\right|_{*} \\
& +\left.\frac{1}{2}\left(\sin \phi_{i}^{*}+1\right) \frac{\partial \sigma_{2 i}}{\partial r_{k}}\right|_{*}
\end{aligned}
$$

$k=m-1$ のとき $\left(r_{m-1}\right.$ は $c$ を意味する $)$

$\left.\frac{\partial Q_{s i}}{\partial c}\right|_{*}=\cos \phi_{i}^{*}$

$k=m$ のとき（ $r_{m}$ は $\phi$ を意味する $)$

$$
\left.\frac{\partial Q_{s i}}{\partial \phi}\right|_{*}=-c_{i}^{*} \sin \phi_{i}^{*}+\frac{1}{2}\left(\sigma_{1 i}^{*}+\sigma_{2 i}^{*}\right) \cos \phi_{i}^{*}
$$

ここで, $\partial \sigma_{1 i} /\left.\partial r_{k}\right|_{*}, \partial \sigma_{2 i} /\left.\partial r_{k}\right|_{*}(k=1,2, \cdots, m-2)$

は

$$
\begin{aligned}
& {\left[\begin{array}{l}
\left.\frac{\partial \sigma_{1 i}}{\partial r_{k}}\right|_{*} \\
\left.\frac{\partial \sigma_{2 i}}{\partial r_{k}}\right|_{*}
\end{array}\right]=\frac{1}{2}\left(\left.\frac{\partial \sigma_{x i}}{\partial r_{k}}\right|_{*}+\left.\frac{\partial \sigma_{y i}}{\partial r_{k}}\right|_{*}\right)} \\
& \pm \frac{\frac{1}{2}\left(\sigma_{x i}^{*}-\sigma_{y i}^{*}\right) \cdot\left(\left.\frac{\partial \sigma_{x i}}{\partial r_{k}}\right|_{*}-\left.\frac{\partial \sigma_{y i}}{\partial r_{k}}\right|_{*}\right)^{2}+\left.2 \tau_{x y i} \cdot \frac{\partial \tau_{x y i}}{\partial r_{k}}\right|_{*}}{2 \sqrt{\left(\frac{\left.\sigma_{x i}^{*}-\sigma_{y i}^{*}\right)^{2}+\tau_{x y i}^{* 2}}{2}\right.}}
\end{aligned}
$$

式 ( 5 ), ( 6 ), ( 7 ), ( 8 ) 中の, $\sigma_{x i}^{*}, \sigma_{y i}^{*}, \tau_{x y i}^{*}, \sigma_{1 i}^{*}$, $\sigma_{2 i}^{*}, \partial \sigma_{x i} /\left.\partial r_{k}\right|_{*}, \partial \sigma_{y i} /\left.\partial r_{k}\right|_{*}, \partial \tau_{x y i} /\left.\partial r_{k}\right|_{*}, \partial \sigma_{1 i} /\left.\partial r_{k}\right|_{*}$, $\partial \sigma_{2 i} /\left.\partial r_{k}\right|_{*}$ は, 要素 $i$ の破壊点 $\left\{r_{1 i}^{*}, r_{2 i}^{*}, \cdots, r_{(m-2) l}^{*}\right\}$ に おける応力と応力の偏導関数の值を示す. 応力の偏導関 数は, 通常の線形一次近似理論を適用した有限要素法で も示されているように，剛性方程式を不確定要因 $r_{k}$ で 微分することによって求めることができる ${ }^{10), 11)}$.

以上のようにして，破壊規準関数 $Q_{s i}$ を，破壊点にお いて線形化することができる.

\section{3. 破壊確率の計算法の提案}

ここで提案する破壊確率の計算法は, 前章で求めた, 線形化された破壊規準関数 $Q_{s i}$ (以下 $Q_{s i}^{\prime}$ としるす）を 積分領域の境界とし, 乱数を用いて破壊確率を求めるも のである.

いま，不確定要因 $\{r\}=\left\{r_{1}, r_{2}, \cdots, r_{m}\right\}$ は，互いに独 立であると仮定しているので, それらの結合確率密度関 数は, 各不確定要因の確率密度関数によって,

$$
f_{r_{1}, r_{2}, \cdots, r_{m}}\left(r_{1}, r_{2}, \cdots, r_{m}\right)=f_{r_{1}}\left(r_{1}\right) \cdot f_{r_{2}}\left(r_{2}\right) \cdots \cdot f_{r_{m}}\left(r_{m}\right)
$$

のように表わされる.これを用いて要素 $i$ の破壊確率は, 破壊点まわりの一次近似により, 次の積分で表わされる.

$$
P_{f, i}=\iint \cdots \int_{D^{\prime}} f_{r_{1}, r_{2}, \cdots, r_{m}}\left(r_{1}, r_{2}, \cdots, r_{m}\right) d r_{1} d r_{2} \cdots d r_{m}
$$

$$
D_{i}^{\prime}=\left\{\left(r_{1}, r_{2}, \cdots, r_{m}\right)\left|Q_{s i}^{\prime}=\sum_{k=1}^{m}\left(r_{k}-r_{k i}^{*}\right) \frac{\partial Q_{s i}}{\partial r_{k}}\right|_{*}<0\right\}
$$

式（10）の重積分は，積分領域が式（11）で示すような 超平面で区切られており, 結合確率密度関数は式（9） のように個々の確率密度関数の積で表わされている.こ の積分は乱数を用いることによって比較的容易に計算す ることができる，つまり，それぞれの確率密度関数に基 ついて発生される乱数の組を, $\left(r_{1}, r_{2}, \cdots, r_{m}\right)$ とし, これらを $N$ 回発生させるとき, 式 (11) を満たす乱数 の組の個数を $N_{F i}$ とすると, 要素 $i$ の破壊確率は,

$$
P_{f, i}=\frac{N_{F i}}{N}
$$

で計算される．この方法によれば, 個々の確率密度関数 が正規分布以外の複雑な分布形であっても，それらに 従った乱数を発生させることによって破壊確率を容易に 計算することができる.

\section{4. 数值計算例}

ここで提案した確率有限要素法の解の精度を検証する ため, 数值計算例を示す. 破壊規準関数 $Q_{s i}$ は式（2） を用い, 不確定要因 $r_{k}$ としては, $P$ (外力), $c$ (粘着 力）の 2 つを考え，その他は確定值とする.ここでは， まず，破壊規準関数 $Q_{s i}$ の破壊点を求める計算手順を示 し, 次に，本手法を用いて破壊確率を求め，モンテカル 口法の解と, 従来の正規分布近似 ${ }^{18)}$ 適用した確率有限 要素法で求めた解との比較検討を行う.

なお， $P, c$ はそれぞれ，対数正規分布，正規分布に 従うとし, それらの平均値を $\mu_{P}, \mu_{c}$, 標準偏差を $\sigma_{P}$, $\sigma_{c}$ とする.

\section{（1）破壊点を求めるための収束計算}

要素 $i$ において, せん断破壊に対する安全性の余裕は,

$$
\begin{aligned}
Q_{s i}= & Q_{s i}(P, c)=c \cos \phi+\frac{1}{2}\left(\sigma_{1 i}+\sigma_{2 i}\right) \sin \phi \\
& -\frac{1}{2}\left(\sigma_{1 i}-\sigma_{2 i}\right) \ldots \ldots \ldots \ldots \ldots \ldots \ldots \ldots \ldots \ldots \ldots \ldots \ldots \ldots \ldots \ldots \ldots \ldots \ldots
\end{aligned}
$$

である.また, 本数値計算において, 要素 $i$ の破壊点は, 図一2に示すように定義される.すなわち， $P, c$ をそ れぞれの平均值 $\mu_{P}, \mu_{c}$ と標準偏差 $\sigma_{P}, \sigma_{c}$ を用いて座標 変換を行った $P^{\prime}-c^{\prime}$ 座標上において, 破壊点は座標原 点から破壊規準関数 $Q_{s i}\left(P^{\prime} \cdot \sigma_{P}+\mu_{P}, c^{\prime} \cdot \sigma_{c}+\mu_{c}\right)=0$ へ下 した垂線の足 $A_{i}^{*}$ で決定される. ここで, 原点から $A_{i}^{*}$ までの距離を $\beta_{i}$, 破壊規準関数の $A_{i}^{*}$ における外向の単 位法線ベクトル $\nu$ の $P^{\prime}$ 成分, $c^{\prime}$ 成分をそれぞれ $\alpha_{P i}$, $\alpha_{c i}$ とすると, 破壊点 $\left\{P_{i}^{*}, c_{i}^{*}\right\}$ は

$$
\begin{aligned}
& P_{i}^{*}=\mu_{P}-\alpha_{P i} \cdot \beta_{i} \cdot \sigma_{P} \\
& c_{i}^{*}=\mu_{c}-\alpha_{c i} \cdot \beta_{i} \cdot \sigma_{c}
\end{aligned}
$$




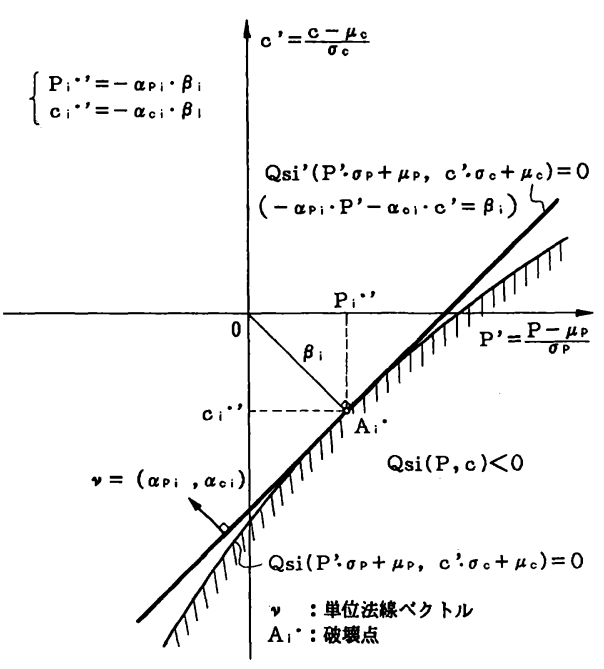

図一2 破轅点の定義

線上の点であるから

$Q_{s i}\left(P_{i}^{*}, c_{i}^{*}\right)=0$

を満たす。

式 (14) 中の $\beta_{i}, \alpha_{P i}, \alpha_{c i}$ は, 以下のように求められ る. 破壊規準関数 $Q_{s i}\left(P^{\prime} \cdot \sigma_{P}+\mu_{P}, c^{\prime} \cdot \sigma_{c}+\mu_{c}\right)=0$ の $A_{i}^{*}$ における接線の方程式は, $\beta_{i}, \alpha_{P i}, \alpha_{c i}$ を用いて

$-\alpha_{P i} \cdot P^{\prime}-\alpha_{c i} \cdot c^{\prime}=\beta_{i} \cdot$

と表わされる.これは $P^{\prime}-c^{\prime}$ 座標上の線形化された破 壊規準関数 $Q_{s i}^{\prime}\left(P^{\prime} \cdot \sigma_{P}+\mu_{P}, c^{\prime} \cdot \sigma_{c}+\mu_{c}\right)=0$ であるので, これを $P^{\prime}, c^{\prime}$ について整理し係数を比較することに よって $\beta_{i}, \alpha_{P i}, \alpha_{c i}$ は

$\beta_{i}=\frac{Q_{s i}\left(P_{i}^{*}, c_{i}^{*}\right)+\left.\left(\mu_{P}-P_{i}^{*}\right) \frac{\partial Q_{s i}}{\partial P}\right|_{*}+\left.\left(\mu_{c}-c_{i}^{*}\right) \frac{\partial Q_{s i}}{\partial c}\right|_{*}}{\left\{\left(\left.\sigma_{P} \frac{\partial Q_{s i}}{\partial P}\right|_{*}\right)^{2}+\left(\left.\sigma_{c} \frac{\partial Q_{s i}}{\partial c}\right|_{*}\right)^{2}\right\}^{1 / 2}}$

$$
\begin{aligned}
\alpha_{P i} & =\frac{\left.\sigma_{P} \frac{\partial Q_{s i}}{\partial P}\right|_{*}}{\left\{\left(\left.\sigma_{P} \frac{\partial Q_{s i}}{\partial P}\right|_{*}\right)^{2}+\left(\left.\sigma_{c} \frac{\partial Q_{s i}}{\partial c}\right|_{*}\right)^{2}\right\}^{1 / 2}} \\
\alpha_{c i} & =\frac{\left.\sigma_{c} \frac{\partial Q_{s i}}{\partial c}\right|_{*}}{\left\{\left(\left.\sigma_{P} \frac{\partial Q_{s i}}{\partial P}\right|_{*}\right)^{2}+\left(\left.\sigma_{c} \frac{\partial Q_{s i}}{\partial c}\right|_{*}\right)^{2}\right\}^{1 / 2}}
\end{aligned}
$$

と書き表わされる. $\partial Q_{s i} / \partial P, \partial Q_{s i} / \partial c$ については, 式 $(5),(6)$ に示すとおりである.

破壊点 $\left\{P_{i}^{*} ， c_{i}^{*}\right\}$ は式 $(14) ，(15) ，(17) ，(18) ，(19)$ より求まるが，一般に，解析的に求めるのは困難である ので収束計算で求める. 収束計算の初期值として, 平均 值 $\mu_{P}, \mu_{c}$ を用いる. これは, 破壊点は図一2に示す原 点 (平均値) の周辺に現われると考えられるからである. ます， $P_{i}^{*}=\mu_{P}, c_{i}^{*}=\mu_{c}$ として式 $(17) ，(18) ，(19)$ よ
り, $\beta_{i}, \alpha_{P i}, \alpha_{c i}$ の值を計算する. 次に，これらの値を もとに式（14）より $P_{i}^{*}, c_{i}^{*}$ を計算する. 以下は，収 束するまでこの操作を繰り返す．収束判定は $\beta_{i}$ の值で 行い

$$
\left|\beta_{i}^{(m)}-\beta_{i}^{(m-1)}\right|<\varepsilon
$$

を満足したときに収束計算を打ち切る。ここで， $\beta_{i}^{(m)}$ は， $m$ 回目の計算における $\beta_{i}$ の值, $\varepsilon$ は収束判定用のパラ メーターである.なお，本数值計算例では $\varepsilon=0.01$ と した，収束計算で得られる $P_{i}^{*} ， c_{i}^{*} よ り$ 線形化された 破壊規準関数は

$$
Q_{s i}^{\prime}=\left.\left(P-P_{i}^{*}\right) \frac{\partial Q_{s i}}{\partial P}\right|_{*}+\left.\left(c-c_{i}^{*}\right) \frac{\partial Q_{s i}}{\partial c}\right|_{*}
$$

と表わされる.

\section{（2）解析モデル}

解析は 2 つモデルを考える. それぞれを図一 $3^{14)}$, 図一4に示す.それぞれのインプットデータは，表一1, 表一2 に示す.

\section{（3）モンテカルロ法との比較}

ここで提案した確率有限要素法の検証として，モンテ カルロ法との比較を行う. モンテカルロ法は, 乱数を発 生することによって得られるインプットデータに対し て, 通常の有限要素解析を行い, 破壊規準関数に基づき 各要素の破壊の有無を調べる.そして，この計算を繰り 返すことによって得られる破壊の回数から各要素の破壊 確率を求めるものである.

a) 解析モデル $(1)^{14)}$

解析モデル（1）は，図一3に示すように 3 要素 4 自 由度のモデルである. 荷重条件としては, 自重, 水平震 度 0.5 および節点集中荷重を与える. 外力 $P$ の確率密 度関数 $f_{P}(P)$ および粘着力 $c$ の確率密度関数 $f_{c}(c)$ は, 次のように書き表わされる.

$$
\begin{aligned}
& f_{P}(P)=\frac{1}{\sqrt{2 \pi} \zeta \cdot P} \exp \left\{-\frac{1}{2}\left(\frac{\ln P-\lambda}{\zeta}\right)^{2}\right\} \\
& f_{c}(c)=\frac{1}{\sigma_{c} \sqrt{2 \pi}} \exp \left\{-\frac{1}{2}\left(\frac{c-\mu_{c}}{\sigma_{c}}\right)^{2}\right\} \\
& \lambda=\ln \mu_{P}-\frac{1}{2} \ln \left(1+\frac{\sigma_{P}^{2}}{\mu_{P}^{2}}\right) \\
& \zeta^{2}=\ln \left(1+\frac{\sigma_{P}^{2}}{\mu_{P}^{2}}\right)
\end{aligned}
$$

これらを用いて, $P$ と $c$ を確率変数とする結合確率密 度関数は, $P$ と $c$ が互いに独立であることより,

$$
f_{P, c}(P, c)=f_{P}(P) \cdot f_{c}(c)
$$

となる. 図一5に，これを各要素の破壊点 $\left\{P_{i}^{*}, c_{i}^{*}\right\}$ と, 線形化された破壊規準関数の限界状態を表わす直線 $\left(Q_{s i}^{\prime}\right.$ $=0$ となる直線）とともに, $P-c$ 座標上に示す. 図中 に示されている破壊点は, 平均值で表わされる点を初期 值とすると, 各要素について 2 回の繰り返し計算で収束 


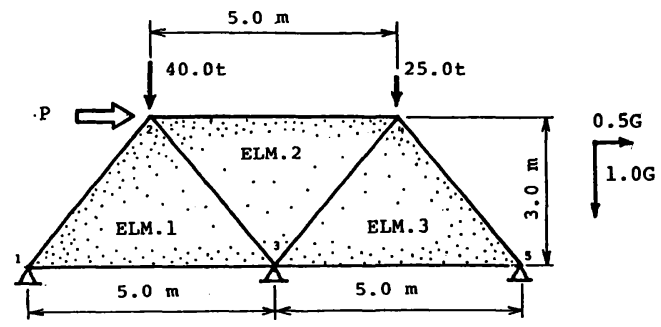

図一3 解析モデル $(1)^{14)}$

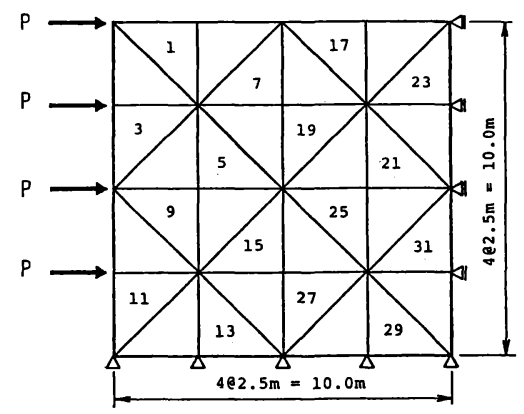

図一4 解析モデル (2)

表一1 インプットデータ（1）

\begin{tabular}{|c|c|c|c|}
\hline & 平 均 值 & 変扐你数 & 分 布 形 \\
\hline ヤング保数 E & $10000.0 \mathrm{tf} / \mathrm{m}^{2}$ & 0.0 & - \\
\hline ポアンン比 & 0.48 & 0.0 & - \\
\hline 単位体磧重量 & $1.8 \mathrm{tf} / \mathrm{m}^{3}$ & 0.0 & - \\
\hline 粘 着 力 & $35.0 \mathrm{tf} / \mathrm{m}^{2}$ & 0.286 & 正 规分布 \\
\hline 内部摩控角 & $30.0^{\circ}$ & 0.0 & - \\
\hline 外 力 & $80.0 \mathrm{tf}$ & 0.4 & 対数正规分布 \\
\hline
\end{tabular}

表一2 インプットデータ

\begin{tabular}{|c|c|c|c|}
\hline & 平均 值 & 変的你数 & 分 布 形 \\
\hline ヤング䋆数 & $10000.0 \mathrm{tf} / \mathrm{m}^{2}$ & 0.0 & - \\
\hline ポアソン比 & 0.48 & 0.0 & - \\
\hline 単位体程重量 & $1.8 \mathrm{tf} / \mathrm{m}^{3}$ & 0.0 & - \\
\hline 粘 普 力 & $10.0 \mathrm{tf} / \mathrm{m}^{2}$ & 0.4 & 対数正规分布 \\
\hline 内部虔㨲角 & $30.0^{\circ}$ & 0.0 & - \\
\hline 外 力 & $80.0 \mathrm{tf}$ & 0.4 & 対数正规分布 \\
\hline
\end{tabular}

した。ここで提案する破壊確率の計算法は，図一5に示 す結合確率密度関数 $f_{P, c}(P, c)$ の斜線側の体積（二次

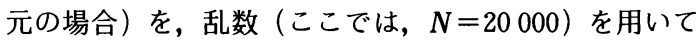
求めるものである.このようにして求めた破壊確率をモ ンテカルロ法で求めた值と比較すると, 図一6のように なる.ここでモンテカルロ法は, 試行回数を種々変化さ せて得た值を示す．この図から，モンテカルロ法によっ て得られる破壊確率は, 試行回数が増加するにつれて, 提案する方法で得られる值に近づくことがわかる.

また，本解析に要した演算時間について，提案する方 法 $(N=20000)$ と, モンテカルロ法(試行回数 20000 回) の比較を表一3に示す．表をみて明らかなように，提案 する方法に要した演算時間は, モンテカルロ法のそれと 比較して，非常に短いことがわかる．これは，モンテカ ルロ法では, 試行回数分だけ有限要素解析を行うのに対 し，提案する方法では，破壊点を求めるための収束計算

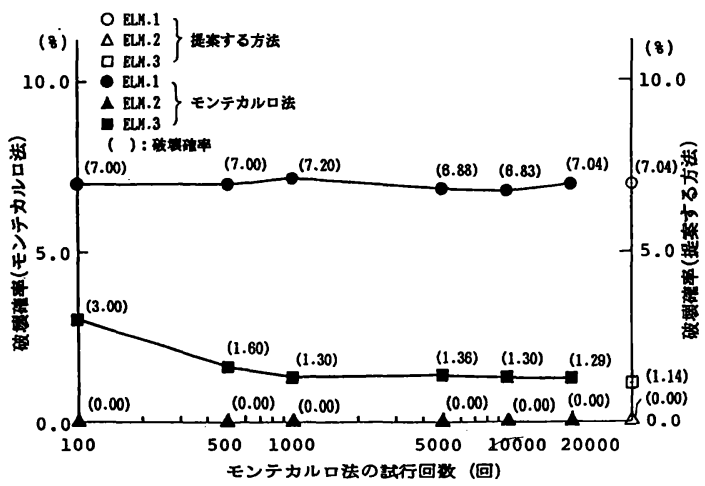

図一6 モンテカルロ法の解との比較（解析モデル $(1)$ )

\section{表一3 演算時間の比較}

\begin{tabular}{|c|c|c|}
\hline & $\begin{array}{c}\text { 提 索する 万方法 } \\
(\mathrm{N}=20000)\end{array}$ & $\begin{array}{c}\text { モンテカルロ 法 } \\
\text { (武行回数 20000回) }\end{array}$ \\
\hline 演算時間(秒) & 3 & 38 \\
\hline
\end{tabular}

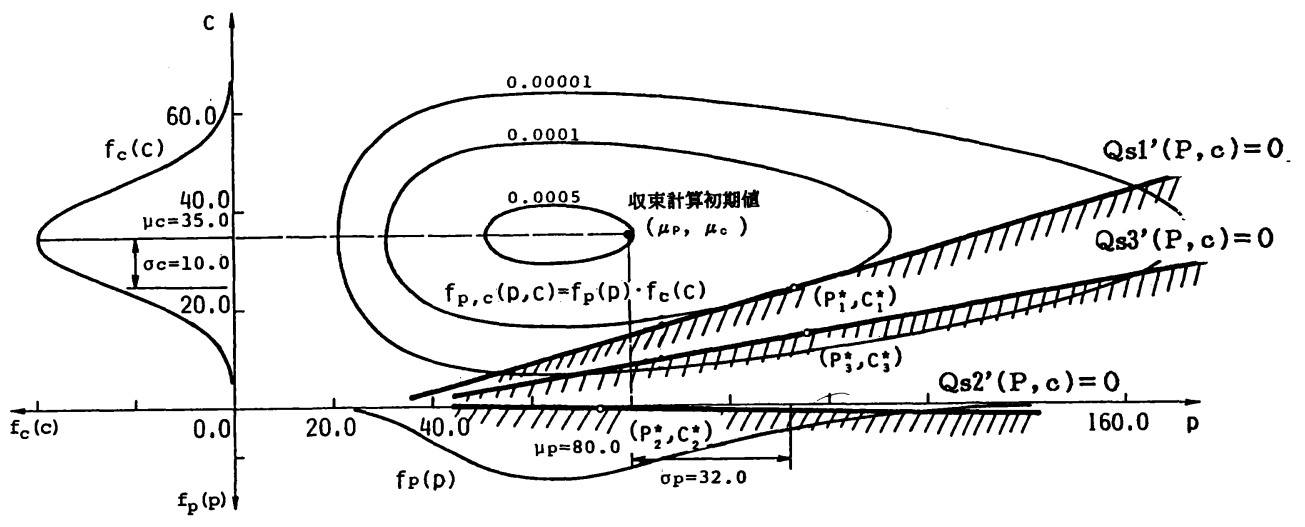

図一5 結合確率密度関数と各要素の線形化された破壊規準関数 $\boldsymbol{Q}_{s i}^{\prime}(\boldsymbol{P}, \boldsymbol{c})$ との関係（解析モデル $\left.(1)\right)$ 
表一4 破壤確率の比較（解析モデル（2））

\begin{tabular}{|c|c|c|c|}
\hline $\begin{array}{l}\text { 要素 } \\
\text { 番号 }\end{array}$ & $\begin{array}{l}\text { 提寀する } \\
\text { 方法(名) }\end{array}$ & $\begin{array}{l}\text { モンテカ } \\
\text { ルロ法( }(x)\end{array}$ & $\begin{array}{c}\text { 荎 } \\
(x)\end{array}$ \\
\hline 1 & 56.82 & 56.76 & 0.10 \\
\hline 3 & 59.72 & 58.62 & 1.87 \\
\hline 5 & 16.19 & 16.28 & -0.55 \\
\hline 7 & 19.20 & 19.02 & 0.85 \\
\hline 9 & 14.52 & 14.32 & 1.40 \\
\hline 11 & 36.05 & 35.22 & 2.35 \\
\hline 13 & 10.45 & 10.80 & -3.24 \\
\hline 15 & 0.00 & 0.04 & - \\
\hline 17 & 35.00 & 33.84 & 3.43 \\
\hline 19 & 11.17 & 11.22 & -0.45 \\
\hline 21 & 0.59 & 0.64 & -7.81 \\
\hline 23 & 11.40 & 11.32 & 0.71 \\
\hline 25 & 0.08 & 0.12 & -25.00 \\
\hline 27 & 0.00 & 0.00 & - \\
\hline 29 & 0.00 & 0.00 & - \\
\hline 31 & 0.00 & 0.00 & - \\
\hline
\end{tabular}

の回数分だけ有限要素解析を行えばよく，その回数がモ ンテカルロ法の試行回数と比較して，はるかに少ないた めである.

\section{b) 解析モデル (2)}

解析モデル（2）は, 図一4に示すように，32 要素 36 自由度のモデルである. インプットデータは表一2に 示すとおりであり, 確率密度関数は, $f_{P}(P), f_{c}(c)$ と も変動係数が 0.4 とかなり大きい, 対数正規分布に従う とする.ここで, 外力は節点間についてばらつかない（完 全相関) とする. 提案する方法における乱数発生回数は $N=10000$ とする.

モンテカルロ法の試行回数を 5000 回としたときの破 壊確率と, 提案する方法で求めた破壊確率の各要素の比 較を表一 4 に示す.これより，破壊確率が $0.7 \%$ 未満の 要素は誤差が $7 \%$ 以上と，大きくなっているが，それ 以外の部分では $4 \%$ 以内に収まっていることがわかる. すなわち, 本手法で求めた各要素の破壊確率はモンテカ ルロ法で求めた破壊確率とほぼ一致するが, 破壊確率が 小さくなる要素 (1％末満) は, 誤差が大きく出ること がある.これは, 積分に乱数を用いているため, 破壊確 率の精度が乱数の発生回数によって決定されるからであ ると考えられる，つまり，N=10000 の場合, 破壊確率 は $0.01 \%$ きざみで算出され, 破壊確率が小さい場合に は，誤差が大きく現われると考えられる.

\section{（4）正規分布近似法との比較}

確率密度関数が正規分布でない場合，それを破壊点に おいて破壊確率が同じになるような正規分布に近似して 破壊確率を求める方法 ${ }^{18)}$ が提案されており，これを確率 有限要素法にも適用できることが示されている(1).

ここでは，提案する方法による解と正規分布近似法に よる解の比較を行う. 計算例として図一3に示す解析モ デル（1）を用いる. 表一5に，それぞれの方法で求め た破壊確率を示す。ここで，提案する方法においては，
表一5 破壊確率の比較（解析モデル $(1)$ )

\begin{tabular}{|c|c|c|c|}
\hline 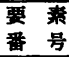 & $\begin{array}{c}\text { 提案する方法(\$) } \\
(N=20000)\end{array}$ & $\begin{array}{l}\text { 正規分布 } \\
\text { 近儌法(\$) }\end{array}$ & $\begin{array}{l}\text { モンテカルロ法(X) } \\
\text { (試行回数 } 20000 \text { 回) }\end{array}$ \\
\hline $\begin{array}{l}1 \\
2 \\
3\end{array}$ & $\begin{array}{l}7.04 \\
0.00 \\
1.14\end{array}$ & $\begin{array}{l}6.11 \\
0.02 \\
0.85\end{array}$ & $\begin{array}{l}7.04 \\
0.00 \\
1.29\end{array}$ \\
\hline
\end{tabular}

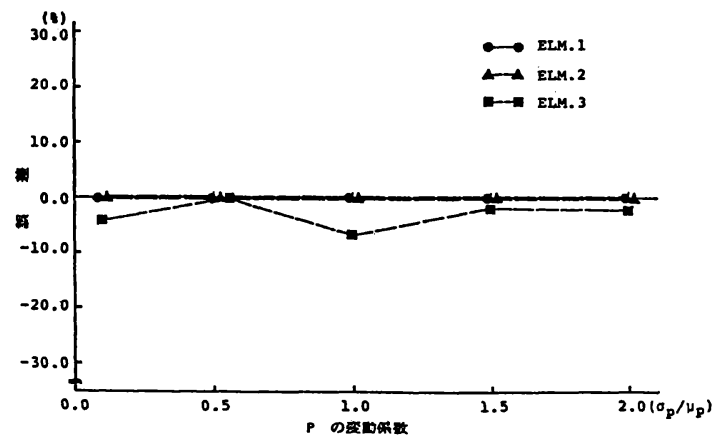

図一7 变動係数の增加に伴う各要素の破懐確率の誤差

乱数発生回数 $N=20000$, モンテカルロ法では試行回数 20000 回とした。これより，提案する方法は，すべての 要素について正規分布近似法よりも, モンテカルロ法の 解に近くなっていることがわかる.

（5）変動係数の増加に伴う各要素の破壊確率の誤差 線形一次近似理論を用いた確率有限要素法の適用限界 の 1 つとして, 確率変数の変動係数が大きくなる場合が 考えられる. 鈴木らは, 確率有限要素法において, 確率 変数の変動係数が大きくなる場合, 図一3に示すモデル に対して，相対誤差が最大で約 $30 \%$ と大きくなること を報告している11).

ここでは, 提案する方法を用いて, 確率変数の変動係 数の増加に伴う各要素の破壊確率の誤差の検討を行う. 解析には，図一3 のモデルを用いて，本手法により得ら れた解とモンテカルロ法により得られた解を比較するこ とによって解の検証を行った. インプットデータは表一 1 に示したものと同じものを用い，外力 $P$ だけを平均 值 $80 \mathrm{t}$ の対数正規分布としてその変動係数を変化させ た. なお，提案する方法においては乱数発生回数 $N=$ 5000 とした. 解の精度は, モンテカルロ法の試行回数 5000 回の結果を正解值として, 本手法で得られた解と の相対誤差により示す. 結果は図一7に示す.

これより, 変動係数が変化しても要素 1 , 要素 2 につ いては，ほとんど誤差が 0 であり，要素 3 については, 多少の誤差は現われるが, それは最大で, 変動係数が 1.0 のときのー $6.5 \%$ であり, 他は $4 \%$ 以内に収まって いる.このことから，ここで提案する確率有限要素法は, 確率変数の変動係数が大きくなる場合でも, 従来の方法 に比較して，精度が向上していることがわかる. 


\section{5.むすび}

本論文においては, 地盤構造物の確率有限要素解析を 対象に, まず, 有限要素法において, 破壊の状態を表わ す破壊規準関数を破壊点において線形化する方法を示 し，次に，線形化された破壊規準関数をもとに乱数によ る積分で，破壞確率を計算する方法を提案した。そして 最後に，具体的な計算例を示し，いくつかのケースにつ いて，局部破壊に対する破壊確率を，ここで提案した方 法, モンテカルロ法および従来の方法によって求め, 考 察を行った，その結果，ここで提案する確率有限要素法 によれば，そのインプットデータとなる材料特性や荷重 などの確率変数が, 正規分布でない分布形に従う場合で あっても, モンテカルロ法の解とほぼ一致する解を容易 に求めることができ，しかも，従来までに提案されてい る方法と比較しても, その精度が向上することが明らか となった。このことは, 確率有限要素法を地盤工学にお ける種々の問題に適用する際に，その汎用性が高められ たことを示していると考えられる.

\section{参 考 文 献}

1) Desai, C.S. : Numerical Methods in Geotechnical Engineering, McGraw-Hill, N. Y., 1977.

2) Gudehus, G. : Finite Elements in Geomechanics, J. Wiley \& Sons, London, 1977.

3) 川本朓万・林 正夫：地盤工学における有限要素解析, 培風館, 1978 .

4）松尾 稔：地盤工学 信頼性設計の理念と実際, 技報堂 出版, 1984.

5) Hoeg, K. and Murarka, R. P. : Probabilistic Analysis and Design of a Retating Wall, ASCE, Vol.100, No. GT 3, pp. 349 366, 1974.

6) Vanmarcke, E. H. : Reliability of Earth Slopes, ASCE, Vol. 103, No. GT 11, pp. 1247 1265, 1977.
7）中桐 滋 - 久田俊明 : 確率有限要素法入門, 培風館, 1985.

8) Vanmarcke, E., Shinozuka, M., Nakagiri, S., Schuëller, G. I. and Grigoriu, M. : Random Field and Stochastic Finite Elements, Structual Safety, 3, pp. 143 166, 1986.

9) Cambou, B. : Application of First-order Uncertainty Analysis in the Finite Element Method in Linear Elasticity, Proc. of 2nd Int. Conf. Applications of Statistics and Probability in Soil and Structural Engineering, Aachen, pp. 67 87, 1975.

10）桜井春輔・土居康成：有限要素法による斜面の信頼性解 析, 土木学会論文報告集, No. 330, pp. 87 97, 1983.

11）鈴木 誠・石井 清': 確率有限要素法による斜面安定解 析, 土木学会論文集, No. 364/III -4, pp. 199 208, 1985.

12) Hasofer, A. M. and Lind, N. C. : Exact and Invariant Second Moment Code Format, ASCE, Vol.100, No. EM 1, pp. 111 121, 1974.

13）辰巳安良・鈴木善雄：確率有限要素法による護岸の信頼 性設計の試み, 土木学会論文集, No. 376/III-6, pp. 49〜 $58,1986$.

14）辰巳安良ほか：確率有限要素法による防波堤の信頼性解 析, 第 19 回土質工学会研究発表会, pp. 897 900, 1984.

15）桜井春輔・清水則一：鈴木 誠·石井 清共著 “確率有 限要素法による斜面安定解析”への討議, 土木学会論文集, No. 376/III-6（討議・回答), pp. 323 324, 1986.

16) Schuëller, G.I. (小西一郎・高岡宣善 - 石川 浩共訳) : 構造物の安全性と信頼性, 丸善株式会社, pp. 241 244, 1984.

17）山本正明・伊藤 洋・本城勇介：土質データーのばらつ きと設計，4. 土質データーのばらつきを考虑した設計， 土と基礎, Vol. 35, No. 5, pp. 69 76, 1987.

18) Rackwitz, R. and Fiessler, B. : Structural Reliability under Combined Random Load Sequences, Computers \& Structures, Vol.9, pp. 489 494, 1978.

19）溜 幸生 : 岩盤構造物の信頼性解析に関する研究, 神戸 大学大学院修士論文, 1987.3.

(1988.4.21 - 受付) 